ZOOLOGIA 28 (2): 145-150, April, 2011

doi: $10.1590 /$ S1984-46702011000200001

\title{
The influence of thymol+DMSO on survival, growth and reproduction of Bradybaena similaris (Mollusca: Bradybaenidae)
}

\author{
Paula Ferreira1,4; Geraldo L. G. Soares²; Sthefane D'ávila³; Elisabeth C. de Almeida Bessa1,3 \\ ${ }^{1}$ Laboratório de Biologia de Moluscos e Helmintos, Pós-graduação em Ciências Biológicas - Comportamento e Biologia \\ Animal, Departamento de Zoologia, Instituto de Ciências Biológicas, Universidade Federal de Juiz de Fora. Rua José Lourenço \\ Kelmer, 36036-900 Juiz de Fora, MG, Brazil. \\ 2 Departamento de Botânica, Instituto de Biociências, Universidade Federal do Rio Grande do Sul. Avenida Bento Gonçalves \\ 9500, 91509-900 Porto Alegre, RS, Brazil. \\ ${ }^{3}$ Museu de Malacologia Professor Maury Pinto de Oliveira, Universidade Federal de Juiz de Fora. Rua José Lourenço Kelmer, \\ 36036-900 Juiz de Fora, MG, Brazil. \\ ${ }^{4}$ Corresponding author. E-mail: paulacertain@gmail.com
}

\begin{abstract}
Bradybaena similaris (Férussac, 1821), commonly known as the Asian trampsnail, is a terrestrial snail native to Asia, introduced in other regions of the world. In Brazil, populations of this land snail are distributed from the state of Amapá in the North to Rio Grande do Sul in the South. This species acts as an intermediate host for parasites and is a difficult-to-control agricultural pest as well, causing great losses to crops and ornamental plant cultivation. This land snail is easily reared in the laboratory and has been successfully used as a biological model in studies that aim at verifying molluscicidal effects of plant extracts. Several studies have demonstrated that $B$. similaris, like many other species of land and freshwater snails, is physiologically adapted to survival over transitory unfavorable environmental conditions. Moreover, this species seems to have a life history strategy characterized by a short life span and a maximal opportunistic reproductive effort during transient favorable periods. Such biological features may potentially lead to the inefficacy of control attempts and, simultaneously, make this species able to repopulate sites previously treated with biocides. For this reason, studies that aim at verifying the effect of molluscicides on the reproduction, growth and survival of molluscs are greatly required. Molluscicides of plant origin may represent a safe and effective way of controlling these animals. Thymol is a substance of plant origin which has bactericidal, fungicidal and anti-inflammatory properties and has been presented as a promissory biocide of mollusc species. The aim of this work was to assess the molluscicidal property of thymol in combination with DMSO against eggs and adults of $B$. similaris. During 120 days, we evaluated the effect of thymol+DMSO at different concentrations $(2.5 \mathrm{~g} / \mathrm{L}$ and $5 \mathrm{~g} / \mathrm{L})$ on the hatching success, hatchling survival, growth and reproduction of $B$. similaris under laboratory conditions. We tested thymol+DMSO on 160 eggs, 160 10-day-old and 16030 -day-old juveniles. The results showed that thymol+DMSO ( $5 \mathrm{~g} / \mathrm{L}$ and $2.5 \mathrm{~g} / \mathrm{L}$ ) affected hatching success, acting as an ovicide. The tests with 10-day-old juveniles showed that thymol+DMSO at $2.5 \mathrm{~g} / \mathrm{L}$ and $5 \mathrm{~g} / \mathrm{L}$ caused 90 and $100 \%$ of mortality, respectively. For the 30-day-old juveniles, thymol+DMSO caused $87.5 \%$ of mortality at $5 \mathrm{~g} / \mathrm{L}$, and $75 \%$ at $2.5 \mathrm{~g} / \mathrm{L}$. With regard to growth, the results were not significant. The 10-day-old individuals treated with thymol+DMSO showed only one reproductive event during the 120 days of the experiment. Thymol+DMSO showed molluscicidal and residual activity, which makes evident its potential for controlling snails, and consequently, snail-borne diseases.
\end{abstract}

KEY WORDS. Control; molluscicide; monoterpene; terrestrial snail.

Bradybaena similaris (Férrusac, 1821) is a terrestrial snail widely distributed in nature, especially in tropical regions. It is native from Asia and was introduced into other regions of the world through plant trading. This snail is considered an agricultural pest due to its preference for plants consumed by humans (LEAHY 1980). It may also act as an intermediate host for parasites such as Postharmostomum gallinum Witenberg, 1923
(Digenea: Brachylaimidae) (Duarte 1980, Amato \& Bezerra 1989), Angiostrongylus costaricensis Morera \& Céspedes, 1971, A. cantonensis (Nematoda: Angiostrongylidae) (RAмво et al. 1997, Jaume et al. 1981, Vargas et al. 1992, Caldeira et al. 2007), and Eurytrema coelomaticum Giard \& Billet, 1882 (Digenea: Dicrocoeliidae) (Pinheiro \& Amato 1995). This snail is resistant to variations in environmental conditions (LEAHY 1980, 1983), 
being able to aestivate in adverse conditions, returning to and recolonizing the site when the environment becomes favorable (Pieri \& Juberg 1981).

To combat these animals, molluscicides of plant origin become important tools because they represent an effective and low-cost way of doing so. Furthermore, these molluscicides have a smaller impact on the environment (Ferreira et al. 2009). Thymol (= 5-metil-2-isopropil-1-fenol) is a monoterpenoid obtained from the essential oil of Laminacea species, such as Monarda punctata L. (mint), Thymus vulgaris L. (thyme) and Thymus persicus $\mathrm{L}$. It is found in products used to combat oral cavity microorganisms, acting as bactericide and fungicide, also having anti-inflammatory properties (BUDAVARI 1989, Wicht et al. 2004, Salgueiro et al. 2003, OкAzAKi et al. 2002). Thymol obtained from the essential oil of Lippia graveolens (Kunth) (Verbenaceae) was also tested as a molluscicide against Biomphalaria spp. (BezerRa et al. 1981). SingH \& SingH (1997) verified the molluscicidal activity of this substance on Lymnaea acuminata by using fruits of Trachyspermum ammi L. (Apiaceae). However, there are few studies evaluating the molluscicidal and ovicidal activity of this substance on terrestrial molluscs (FerReira et al. 2009).

The aim of this work was to evaluate the influence of thymol+DMSO on the development of eggs, survival, growth and reproduction of 10-day and 30-day-old B. similaris snails during 120 days.

\section{MATERIAL AND METHODS}

\section{Rearing of the snails and preparation for tests}

Laboratory colonies were established from specimens collected in the municipality of Juiz de Fora, Minas Gerais $\left(21^{\circ} 45^{\prime} 50^{\prime \prime} \mathrm{S}, 43^{\circ} 21^{\prime} 0^{\prime \prime} \mathrm{W}\right)$ ( $678 \mathrm{~m}$ altitude). The tropical weather typical of this locality is characterized by two well-defined seasons: a dry winter with relatively low temperatures, which extends from May to September and a rainy summer with higher temperatures, from October to April. The average annual temperature is $19.3^{\circ} \mathrm{C}\left(15-24^{\circ} \mathrm{C}\right)$ and the annual rainfall is $1627 \mathrm{~mm}$. Newly hatched snails of the same age, obtained from these colonies, were used to establish a second colony, which served as the source for all the eggs and individuals used in this work.

The snails were kept in polythene boxes. Each box was lined with previously sterilized $\left(120^{\circ} \mathrm{C} / 1 \mathrm{~h}\right)$ humus and covered with cotton fabric. These terraria were moistened with water every three days, when the snail food was also renewed. The snails were fed ad libitum with commercial poultry food (composed of a mixture of corn meal, soy meal, wheat bran, gluten bran, chicken flesh and bone meal, fish meal, calcium phosphate, and sodium chloride) supplemented with minerals, vitamins and calcium carbonate (Bessa \& ARAújo 1995). The snails were kept at room temperature and under natural light conditions. The minimum and maximum temperature (19- $\left.23,5^{\circ} \mathrm{C}\right)$ and the relative humidity $(72 \%)$ were recorded daily with a thermometer and a thermohygrometer (Incoterm ${ }^{\hat{a}}$ ).

A total of 160 eggs, 160 10-day-old juveniles and 160 30day-old juveniles were used in the experiments. The snails of the two age groups were distributed at random, in groups of 10 individuals per terrarium (polythene boxes, $12 \mathrm{~cm}$ wide $\mathrm{x} 9 \mathrm{~cm}$ long). The eggs were placed in $9 \mathrm{~cm}$ wide $\mathrm{x} 6.2 \mathrm{~cm}$ long terraria.

Forty eggs, forty 10-day-old juveniles and forty 30-dayold juveniles were assigned to test with thymol+DMSO solutions at $2.5 \mathrm{~g} / \mathrm{L}$. The same amount of eggs and juveniles of the two age groups was assigned to tests with thymol+DMSO solutions at $5 \mathrm{~g} / \mathrm{L}$, as well as to the DMSO-control group (drinking water+DMSO) and the water-control group (drinking water).

To obtain the thymol-DMSO solutions used in the tests, we used drinking water heated to $60^{\circ} \mathrm{C}$ and added dimethyl sulfoxide P.A. (ISOFARâ) (DMSO) at $1 \%$, which acted as an emulsifier in order to dilute the thymol (ISOFAR ${ }^{a}$ ) which is insoluble in water.

\section{Experiment I: Assessing the influence of thymol+ DMSO on the hatching of juvenile hatchlings from treated eggs}

Eggs, in groups of 10, were placed inside $5 \mathrm{~cm}$ diameter and $4 \mathrm{~cm}$ deep plastic boxes, in contact with $5 \mathrm{ml}$ of the thymol+DMSO solutions, at $2.5 \mathrm{~g} / \mathrm{L}$ or $5 \mathrm{~g} / \mathrm{L}$, for 10 minutes (Ferreira et al. 2009). Eggs of the DMSO-control group were placed in contact with $1 \%$ DMSO drinking water and the water-control group with only drinking water. After each 10 minute period, the eggs were removed from the solutions, returned to their respective terrarium, and observed daily to evaluate hatching success and hatchling survival.

Experiment II: The influence of thymol+DMSO on
survival, growth and reproduction of 10-day and
30-day-old juveniles
Juveniles were first left fasting for 24 hours. After this period, they were distributed with the aid of a brush, in groups of 10 , in $5 \mathrm{~cm}$ diameter and $4 \mathrm{~cm}$ deep plastic containers, staying in contact with $5 \mathrm{ml}$, of either $2.5 \mathrm{~g} / \mathrm{L}$ or $5 \mathrm{~g} / \mathrm{L}$, thymol+DMSO solutions, for 10 minutes. The DMSO-control group received $1 \%$ DMSO drinking water and the water-control group only received drinking water. After this period, the juveniles were removed from the solution and returned to their respective terrarium.

The survival, growth and reproduction of the individuals from the treatment and control groups were verified during 120 days. The growth of the snails was evaluated through biweekly measurements of shell diameter until their $120^{\text {th }}$ day of life. Shell measurements were made using a Kanon calliper to a $0.1 \mathrm{~mm}$ precision, at 15 -day intervals. Survival and reproduction was verified every three days. For the statistical analysis of the data, we used the analysis of variance test (one way ANOvA), with a confidence interval of $95 \%$, the Tukey-Kramer test and the Student's t-test. 


\section{RESULTS AND DISCUSSION}

\section{Experiment I: Assessing the influence of thymol+} DMSO on the hatching of juveniles from treated eggs

Thymol+DMSO acted as an ovicide causing a 100\% mor-

tality of the treated eggs. The results showed that no hatching occurred from eggs treated at either $2.5 \mathrm{~g} / \mathrm{L}$ or $5 \mathrm{~g} / \mathrm{L}$, whereas the mean hatching success was $20 \%$ in the DMSO-control group, and $82 \%$ in the water-control group. There was a significant difference $(p=0.001)$ between the mean hatching success of the groups treated with thymol+DMSO at the two concentrations and the two control groups.

These results show that thymol+DMSO, at these concentrations, can act as a potent ovicide. As seen, ovicidal activity of thymol+DMSO upon the eggs of B. similaris may represent an efficient way of controlling these snails, since this species performs many egg-laying events, becoming an agricultural pest. An efficient treatment also depends on the elimination of eggs, since their permanence may allow a new colonization. Souza et al. (1984) tested the molluscicidal activity of 159 extracts from 84 Brazilian plants and verified that only $11.2 \%$ of the extracts were active against the egg masses of Biomphalaria glabrata, Say 1818. Those authors considered as active the extracts that killed from $50 \%$ to $100 \%$ of the embryos. Souza et al. (1987) also verified that the concentration of the butyl extract of Phytolacca dodecandra L., necessary to reach the $\mathrm{LC}_{90}$ on the egg masses was 22 times greater than the $\mathrm{LC}_{90}$ for adult snails, most probably because the eggs have a shell that may be acting as a protective barrier, preventing the action of the molluscicides. This difficulty in eliminating the egg masses was confirmed by Pereira \& SouzA (1974), who verified that the egg masses of B. glabrata were between 10 to 20 times more resistant to the hexane extract of cashew shells. FerReira et al. (2009) verified moluscicidal activity of the thymol against eggs of the land snail Subulina octona. However, the observed mortality was not $100 \%$, probably because the eggs of that species have a calcified shell, which prevents the penetration of the molluscicidal substance. SIMON et al. (1995) verified the ovicidal activity of extracts from seeds of Milletia thonningii (Leguminosae) on egg masses of $B$. glabrata. The tests were performed with solutions at concentrations of 80,20 and $5 \mathrm{mg} / \mathrm{L}$. The results showed that the extract of this plant interrupted the embryonic development of the eggs, causing the embryos' death. AнмED \& HABiB (2003) verified that the oil extracted from the Comiphora molmol plant at $80 \mathrm{mg} / \mathrm{L}$ acted as an ovicide on the egg masses in initial stage of development, whereas the eggs with a more advanced embryonic development were less susceptible.

The low hatching success of the DMSO-control group suggests that this substance also has an ovicidal effect against the eggs of $B$. similaris, potentially enhancing the efficacy of thymol alone. DMSO has a synergistic activity with thymol, as it probably helps with egg penetration. Besides, the use of DMSO and thymol together is considered to be a safe ovicidal, because DMSO is only toxic in high concentrations.

Experiment II: The influence of thymol+DMSO on the survival, growth and reproduction of 10 and 30-day-old juveniles

10-day-old juveniles treated with thymol+DMSO

Thymol in combination with DMSO worked as a molluscicide on 10-day-old juveniles, causing 90 and $100 \%$ mortality at 2.5 and at $5 \mathrm{~g} / \mathrm{L}$, respectively. This shows its potential for acting against juvenile snails, whose susceptibility is different from that of adults and egg masses. There was a significant difference $(\mathrm{p}<0.0001)$ between the mean survival of the individuals treated with thymol+DMSO at the two concentrations with their respective control groups, during the first 72 hours post-treatment. There was also a significant difference between the mean survival of snails of the two groups treated with thymol+DMSO at $2.5 \mathrm{~g} / \mathrm{L}$ and $5 \mathrm{~g} / \mathrm{L}$, respectively, and also between the mean survival of snails from the DMSO-control group and from the water-control group (Tab. I). No deaths were verified after 72 hours during the entire experiment, which lasted 120 days. FerReira et al. (2009) verified molluscicidal activity of thymol on S. octona only for 30-day-old juveniles.

Table I. Survival of 10 day B. similaris juveniles treated with thymol, 72 hours after exposition. Values with different letters are significantly different.

\begin{tabular}{ccc}
\hline Treatment & Survival $\mathrm{X} \pm \mathrm{SD}$ & Percent survival \\
\hline Thymol $5 \mathrm{~g} / \mathrm{L}$ & $0 \pm 0^{\mathrm{a}}$ & 0 \\
Thymol $2.5 \mathrm{~g} / \mathrm{L}$ & $1.5 \pm 1.2^{\mathrm{b}}$ & 10 \\
Control DMSO & $9.0 \pm 1.4^{\mathrm{c}}$ & 90 \\
Control water & $9.7 \pm 0.5^{\mathrm{d}}$ & 97 \\
\hline
\end{tabular}

No escape behavior was observed in response to the treatment with thymol+DMSO at the two concentrations. This indicates that thymol+DMSO is not a repellent for this species at these concentrations. The repellency to a product might make the molluscicidal activity difficult, favoring the survival of the snails. According to Rey (1973), the "irritative action" of a substance causes the snails to leave the application area.

The use of less toxic substances for the control of these animals represents a minor aggression not only to the environment but also to humans, since these snails feed mainly on vegetables, besides also feeding on ornamental plants. Hence, the use of toxic substances might contaminate products destined for human consumption, with unpredictable consequences, since there is metaldehyde in the base of compounds commonly used to combat snails. Metaldehyde is very toxic to humans, causing severe intestinal irritation and damage to the liver and kidneys, and its use has even been prohibited in some countries (Hollingsworth et al. 2002). 
Thymol+DMSO did not influence the growth of the treated juveniles at 10 days post-hatching. There was no significant difference $(\mathrm{p}=0.36)$ between the mean of treatment and control groups.

There was no significant difference with respect to attainment of sexual maturity, which happened on the $105^{\text {th }}$ day post-hatching. The snails treated with thymol+DMSO at $2.5 \mathrm{~g} /$ L laid eggs only once, confirmed after the presence of 9 hatchlings (11.25\% hatching success) was observed in the terrarium, whereas among the DMSO-control group the presence of 54 hatchlings (67.5\% hatching success) was observed, and in the water-control group the number of hatchlings was 64 (80\% hatching success).

\section{0-day-old juveniles treated with thymol+DMSO}

Thymol in combination with DMSO also worked as a molluscicide on the 30-day-old juveniles, causing a mortality of 95 and $87.5 \%$ in the groups treated with thymol+DMSO at 2.5 and $5 \mathrm{~g} / \mathrm{L}$, respectively. There was a significant difference $(p<0.0001)$ between the mean survival of the individuals treated with thymol+DMSO at $2.5 \mathrm{~g} / \mathrm{L}$ and the ones treated at $5 \mathrm{~g} / \mathrm{L}$, as well as in comparison with the mean of the control groups during the first 72 hours. The difference between the mortalities of the groups treated with thymol+DMSO at 2.5 and $5 \mathrm{~g} / \mathrm{L}$ was also significant (Tab. II).

Table II. Survival of 30 day old $B$. similaris juveniles treated with thymol, 72 hours after exposition. Values with different letters are significantly different.

\begin{tabular}{lcc}
\hline Treatment & Survival $\mathrm{X} \pm \mathrm{SD}$ & Percent Survival \\
\hline Thymol $5 \mathrm{~g} / \mathrm{L}$ & $1.25 \pm 1.50^{\mathrm{a}}$ & 12.5 \\
Thymol 2,5g/L & $0.50 \pm 0.50^{\mathrm{b}}$ & 5.0 \\
Control DMSO & $9.75 \pm 0.50^{\mathrm{c}}$ & 97.5 \\
Control water & $10.0 \pm 0^{\mathrm{c}}$ & 100 \\
\hline
\end{tabular}

For the field use of a molluscicide and the obtainment of an effective control of snail populations, physiological and behavioral strategies - such as aestivation, retraction of the cephalopodal mass into the shell and burying - must be evaluated. Since these behaviors guarantee the survival during unfavorable periods with high temperatures (ARAD 1993, EMBERTON 1994) they may also favor survival to the molluscicides. Pieri \& Juberg (1981) point out that the survival ability in a quiescent physiological state, after retraction into the shell, is one of the main causes for the inefficacy of molluscicide application. The epiphragm formation on B. similaris, observed by D'Ávila et al. (2004), constitutes a potential mechanical barrier to the action of molluscicides, since it may prevent the penetration of the substance. Thus, the application of these substances must be associated with studies on physiological and behavioral patterns exhibited by the target species. Sur- vival during periods of drought has been pointed out as one of the major causes for the inefficacy of molluscicide treatments (Pieri \& Juberg 1981).

LEAHY (1980) verified that B. similaris was greatly resistant to adverse conditions, with a minimum mortality rate being reached after 60 days without food or water, in a low humidity environment. Beside the behavioral adaptive value in regions with prolonged dry periods, its role on the survival of individuals exposed to molluscicides, even in permanent habitats, cannot be neglected (PIeri \& Juberg 1981). Even a small capacity to take shelter in the substrate for short periods would be of a considerable value to snail survival after brief and sporadic applications of molluscicides.

Thymol in combination with DMSO did not interfere in the growth of the juveniles treated at 30 days of age $(p=0.47)$. During the 120 days of the experiment, only the snails of the water-control group laid eggs, with a hatching success of $73.7 \%$.

SINGH \& SINGH (2000) verified the effects on the reproduction of snails of different combinations of MGK-264 (N-acetyl bicyclohepatene dicarboxymide) and PB (Piperonyl Butoxide) plant extracts. The results showed that the treatment with thymol+DMSO at $20 \%$ and $60 \%$ of the $\mathrm{LC}_{50}$ combined with $\mathrm{PB}$ or MGK-264 acted upon Lymmaea acuminata fecundity, inhibiting its reproduction. The effects of this combination are not mentioned in the literature. However, some studies report that some molluscicidal substances reduce oxygen capture, with ultimate effects on metabolism, resulting in low fecundity. Other works indicate the reduction of prostaglandin. According to SINGH \& Agarwal (1981), prostaglandin increases the fecundity of $L$. acuminata species and restores fecundity in sterile snails.

Several studies have demonstrated that $B$. similaris, like many other species of land and freshwater snails, is physiologically adapted to survival over unfavorable transient environmental conditions. Moreover, this species seems to have a life history strategy characterized by a short life span and a maximal opportunistic reproductive effort during favorable transient periods. Such biological features may potentially lead to the inefficacy of control attempts and, simultaneously, make this species able to repopulate sites previously treated with biocides. For this reason, studies that aim at verifying the effect of molluscicides over the reproduction, growth and survival of molluscs are greatly required. The results of the present work show that thymol+ DMSO have molluscicidal, ovicidal and residual activity, affecting snail survival, reproduction and hatching success. These effects show the potential use of this substance for controlling terrestrial snails, and consequently, snail-borne diseases.

\section{LITERATURE CITED}

Ahmed, M.A. \& F.S.M. Навів. 2003. The effects of myrrh (Commiphora molmol) on the infected snails pf Schistosoma sp. and their egg masses: effect on shedding of cercacariae and on snail fecundity. Journal of Egyptian Society of 
Parasitology 33 (2): 585-596.

Amato, S.B. \& J.C.B. Bezerra. 1989. Parasitismo natural de Bradybaena similaris (Férussac, 1821) por Postharmostomum gallinum Witenberg, 1983. Memórias do Instituto Oswaldo Cruz 84 (1): 75-79.

ARAD, Z. 1993. Water relations and resistance to dessication in three Israeli desert land snails, Eremina desertorum, Euchondrus desertorum and Euchondrus albulus. Journal of Arid Environments 24: 387-395.

Bessa, E.C.A. \& J.L.B. Araújo. 1995. Oviposição, tamanho de ovos e medida do comprimento da concha em diferentes fases do desenvolvimento de Subulina octona (Brugüére, 1789) (Pulmonata, Subulinidae) em condições de Laboratório. Revista Brasileira de Zoologia 12 (3): 647-654.

Bezerra, P.; A.G. Fernandes; A.A. Craveiro; C.H.S. Andrade; F.J.A. Matos; J.W. Alencar; M.I.L. Machado; G.S.B. Viana; F.F. MaTos \& M.Z. RouQuaYrol. 1981. Composição química e atividade de óleos essenciais de plantas do nordeste - Gênero Lippia. Ciência \& Cultura 33: 1-14.

Budavari, S. 1989. The Merck index - An encyclopedia of chemicals, drugs and biological. Rahway, Merck \& Co., Inc., $17^{\text {th }}$ ed., $1606 \mathrm{p}$.

Caldeira, R.L.; C.L.G.F. Mendonça; C.O. Gouveia; H.L. Lenzi; C. Graff-Teixeira; W.S. Lima; E.M. Mota; I.L. Pecora; A.M.Z. Medeiros \& O.S. Carvalho. 2007. First record of molluscs naturally infected with Angyostrongylus cantonensis (Chen, 1935) (Nematoda: Metastrongylidae) in Brazil. Memórias do Instituto Oswaldo Cruz 102 (7): 887-889.

D’Ávila, S.; R.J.P. Dias; E.C.A. BESSA \& E. DAEmon. 2004. Resistência à dessecação em três espécies de moluscos terrestres: Aspectos adaptativos e significado para o controle de helmintos. Revista Brasileira de Zoociências 6: 115-127.

Duarte, M.J.F. 1980. O ciclo evolutivo de Postharmostomum gallinum Witenberg, 1923, no Estado do Rio de Janeiro, Brasil (Trematoda, Brachylaemidae). Revista Brasileira de Biologia 40 (4): 783-809.

EMberton, K.C. 1994. Morphology and aestivation behaviour in some Madagascan acavid land snails. Biological Journal of the Linnean Society 53: 175-187.

Ferreira, P.A.; L.G. Soares; S. D'Ávila \& E.C.A. Bessa. 2009. The influence of caffeine and thymol on survival, growth and reproduction of Subulina octona (Brugüère, 1789) (Mollusca, Subulinidae). Brazilian Archives of Biology and Tecnology 52 (4): 945-952.

Hollingsworth, R.G.; J.W. Armstrong \& E. Campbell. 2002. Caffeine as a repellent for slugs and snails. Nature 417: $915-$ 916.

Jaume M.L.; G.P. Puga \& P.H. Aguiar. 1981. Bradybaena similaris (Férussac): hospedeiro intermediário de Angiostrongylus cantonensis em Cuba. Revista Cubana de Medicina Tropical 33: 207-209.

LEAHY, W. 1980. Aspectos adaptativos de Bradybaena similaris Ferussac, 1821 (Mollusca, Gastropoda, Pulmonata) subme- tido ao jejum e dessecação. Boletim de Fisiologia Animal 5: 47-55.

LeAHY, W. 1983. Comportamento e características anatomofuncionais da reprodução em Bradybaena similaris (Molusco pulmonado). Ciência e Cultura 36 (98): 1389-1392.

Okazaki, K.; K. Kawazoe \& Y. Takaishi. 2002. Human platelet aggregation inhibitors from thyme (Thymus vulgaris L.). Phytotherapy Research 16 (4): 398-399.

Pereira, J.P. \& C.P. SouzA. 1974. Ensaios preliminares com "Anacardium occidentale" como moluscicida. Ciência e Cultura 26: 1054-1057.

Pieri, O. \& P. Jurberg. 1981. Aspectos etológicos na sobrevivência dos caramujos vetores da xistosomose ao tratamento com moluscicidas. Memórias do Instituto Oswaldo Cruz 76 (1): 47-55.

Pinheiro, J. \& S.B. Аmato. 1995. Eurytrema coelomaticum (Digenaea, Dicrocoellidae): the effect of infection on carbohydrate contents of its intermediate snail host, Bradybaena similaris (Gastropoda, Xanthonychidae). Memórias do Instituto Oswaldo Cruz 89 (3): 407-410.

Rambo, P.R.; A.A. Agostini \& C. Graff-Teixeira. 1997. Abdominal angiostongylosis in Southern Brazil - prevalence and parasitic burden in mollusc intermediate hosts from eighteen endemic foci. Memórias do Instituto Oswaldo Cruz 92 (1): 9-14.

Rey, I. 1973. Parasitologia. Rio de Janeiro, Guanabara-Koogan, $695 p$.

Salgueiro, L.R.; C. Cavaleiro; M.J. Gonçalves \& A. Proença da CuNHA. 2003. Antimicrobial activity and chemical composition of the essencial oil of Lippia graveolens from Guatemala. Planta Médica 69 (1): 80-83.

Simon, S.H.T.; P.J. Whitifield \& S. Perrett. 1995. Activity of the molluscicidal plant Millettia thonningii (Leguminosae) toward Biomphalaria glabrata eggs. Journal of Parasitology 81 (5): 833-835.

Singh, O. \& R.A. Agarwal. 1981. Toxicity of certain pesticides to two economic species of snails in northem India. Journal of Economic Entomology 74: 568-571.

SingH, S. \& D.K. SingH. 1997. Molluscicidal activity of some common spice plants. Biological Agriculture and Horticulture 14 (3): 237-249.

SingH, K. \& D.K. Singh. 2000. Effect of different combinations of MGK-264 or Piperonyl Butoxide with plant-derived molluscicides on snail reproduction. Archives of Environmental Contamination and Toxicology 38: 182-190.

Souza, C.P.; M.L.L. Azevedo; J.L.C. Lopes; S.J. Sarti; D.S. Filho; J.N.C. Lopes; V. Vichnewski; A.M.T.T. NASI \& F.H. LeITÃo-Filho. 1984. Quimioprofilaxia da esquistossomose: atividade moluscicida de produtos naturais - ensaios com caramujos adultos e desovas. Anais da Academia Brasileira de Ciências 56 (3): 333-338.

SouZa, C.P.; N.M. Mendes; N. Araújo \& N. Katz. 1987. Atividade moluscicida do extrato butílico de Phytolaca dodecandra so- 
bre Biomphalaria glabrata. Memórias do Instituto Oswaldo Cruz 82: 345-359.

Vargas, M.; J.D.G. Perez \& E.A. Malek. 1992. First record of Angistrongylus cantonensis (Chen, 1935) (Nematoda: Metastrongylidae) in the Dominican Republic. Tropical
Medicine and Parasitology 43: 253-255.

Wicht, M.J.; R. HaAk; H. Schütt-GerowitT; S. Kneist \& M.J. Noack. 2004. Suppression of caries-related microorganisms in dentine lesions after short-term chlorhexidine or Antibiotic treatment. Caries Research 38: 436-441.

Submitted: 19.X.2009; Accepted: 22.IX.2010.

Editorial responsibility: Pedro Gnaspini 